\title{
日本人の自律神経緊張状態に関する研究補遺
}

\author{
第 1 編 自律神経緊張状態の男女及び \\ 年令による美異
}

Further Studies on Conditions of Autonomic Nervous

System among Japanese

Part I. Studies on Sex and Age Difference in

Conditions of Autonomic Nervous System

慶応義塾大学医学部衛生学・公衆衛生学教室（主任 原 島 進 教授）

$$
\begin{aligned}
& \text { 宮坂 登志子 } \\
& \text { Toshiko Miyasaka }
\end{aligned}
$$

Department of Preventive Medicine and Public Health, School of Medicine, Keio University

(Director : Prof. S. Harashima)

最近本教室では体質としての自律神経緊張状態を追及 する十連の研究がなされている。原島1)，小川22 は自律 神経体貿加ら久て南方民族は北方民族に比較して副交感 神経緊舞状態て傾いているととを確認し，外山3) は本邦 で季節と自律神経緊張状態の変動を認め，また 渡辺4) は薬効的及び理学的検査の判定規準を定め, 更に血液成
分5) から逆に自律神経の緊張状態をらかがつた。著者は この自律神経緊張状態が性別により，また年令によりど のよらに変動するかを推察しよらと試みた。

\section{1. 被検者及び実験方法}

被検者は外山³) とよつて検査された男子 374 名，女子 194名, 合計568名の健康成人と, 著者の椧査による10才

\begin{tabular}{|c|c|c|c|c|c|c|c|c|c|}
\hline \multirow{2}{*}{ 季 節 } & \multirow{2}{*}{$\begin{array}{l}\text { 男 } \\
\text { 㓱 }\end{array}$} & \multicolumn{4}{|c|}{ 血清カリウム $\mathrm{mg} / \mathrm{dl}$} & \multicolumn{4}{|c|}{ 血清カルシウム mg/dl } \\
\hline & & $\mathbf{n}$ & M & $\mathrm{m}$ & $\sigma$ & $\mathrm{n}$ & $\mathbf{M}$ & $\mathbf{m}$ & $\sigma$ \\
\hline \multirow{2}{*}{$\begin{array}{c}\text { 年 間平均值 } \\
\text { （成人） }\end{array}$} & 今 & 351 & 19.65 & 0.156 & 2.074 & 370 & 10.33 & 0.038 & 0.738 \\
\hline & 우 & 177 & 19.54 & 0.180 & 2.400 & 187 & 10.09 & 0.052 & 0.714 \\
\hline \multirow{2}{*}{ 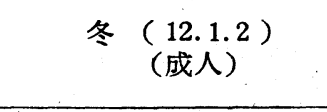 } & 今 & 116 & 20.38 . & 0.167 & 1.722 & 125 & 10.19 & 0.067 & 0.752 \\
\hline & 우 & $5 \dot{7}$ & 20.69 & 0.232 & 1.689 & 58 & 9.96 & 0.113 & 0.859 \\
\hline \multirow{2}{*}{ 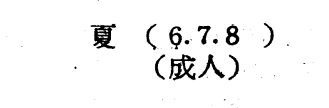 } & 今 & 112 & 18.74 & 0.201 & 2.122 & 118 & 10.40 & 0.083 & 0.906 \\
\hline & 우 & 50 & 17.84 & 0.276 & 1.952 & 51 & 10.37 & 0.094 & 0.593 \\
\hline \multirow{2}{*}{ 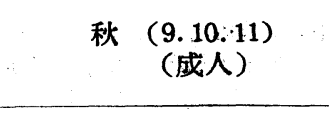 } & 今 & 68 & 20.34 & 0.237 & 1.955 & 72 & 10.48 & 0.075 & 0.638 \\
\hline & 우 & 30 & 20.19 & 0.440 & 2.410 & 40 & 10.16 & 0.097 & 0.615 \\
\hline \multirow{2}{*}{ 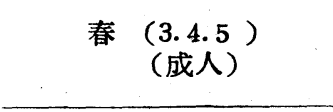 } & 今 & 55 & 19.07 & 0.251 & 1.841 & 55 & 10.31 & 0.099 & 0.724 \\
\hline & 今 & 41 & 19.56 & 0.400 & .2 .561 & 41 & 9.91 & 0.111 & 0.677 \\
\hline \multirow{2}{*}{$\begin{array}{c}3 \text { 月.5月.11月 } \\
\text { (学童) }\end{array}$} & 今 & 96 & 17.68 & 0.267 & 2.649 & 96 & 10.52 & 0.079 & 0.772 \\
\hline & 우 & 112 & 18. 24 & 0.253 & 2.678 & 112 & 10.47 & 0.039 & 0.416 \\
\hline
\end{tabular}

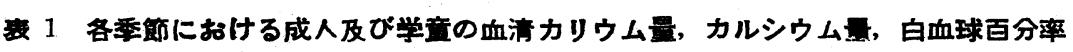


- 1才の男子97名, 女子115名, 合計212名の健康学童で ある。検査期間は成人は昭和 22 年 3 月から同 23 年 2 月 での 1 年間に検査し, 学童は昭和?2年11月から同 24 年 3 月までの間の季節変動の少ない3） 3 月，5月，11月に主と して検查した。

検查は血清 $\mathrm{K}$ 量, $\mathrm{Ca}$ 量及び $\mathrm{K} / \mathrm{Ca}$ 值, 白血球数,白血 球百分率及び平均核数の各項目について行らために，ま ず时静脈から7一-8cc採血し，その一部で直ちに血液塗抹 標本を作り，次の数滴をメランジュールに吸引して白血 球数算定用とし，残りを隇菌試験管に注いで血清化学成 分測定用とした。採血はすべて午前10時から12時の間の 安静時に実施し，血清分離は2時間以内に行つた。

血清 $\mathrm{K}$ 量は血清 $1.0 \mathrm{cc}$ Kつレてクレーマー,ティスド 几氏法 ${ }^{6}$, 血清Ca量は血清1.0cckついてクラーク，コリ ップ氏法てにより，溶血を認めをものはすべて除外し， 定量はその日のらちに行つた。白血球数算定はビュルケ ル，チュルク氏血球計算板を使用した。白血球百分率は 幅 $2 \mathrm{~cm}$ の可及的薄塗抹標本を定規を用いて縁が正し く水平になるよら反作り,ジェンナー，ギームザ氏二重 染色を施し,塗抹面の中央の両縁 $1 \mathrm{~mm}$ の間を屈折法 ${ }^{81}$ に 上り各 100個づつ合計 200個を観察した。平均核数は中 性好性白血球 100個について 杉山氏沠9） によつて計算 した。

\section{2. 測 定 結 果}

血清 $\mathrm{K}$ 量, $\mathrm{Ca}$ 量, 中性好性白血球，リンパ球及び酸好 性白血球の 5 項目について，それらの年間平均値，季節 平均値, 標準誤差及び標淮偏差を計算した結果は表 1 亿 示すとおりである。表のnは各被検者数，M恪平均值， $\mathrm{m}$ は標準誤差及び $\sigma$ は標準偏差を示す。

男女間の最も大なる差は成人では血清 $\mathrm{Ca}$ 量であるが, その有意性を統計的に標準誤差によつて調べをが，有意 の差を見出さなかうた。

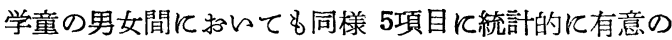
差を見出さなかつた。

てれを更に 5項目の揃つている成人男子 329 名と成人 女子 167名について，また学童男子 91 名と学童女子 105 名について，原島1)，小川22による血液成分の総合法に よつて調べた。即ちての場合，成人は各項目の各個人値 が規正すべき標準值からへだたつている偏差を年間平均 值の標準偏差で除した商を（規正した偏差） 5 項目につ いて求め, 血清 $\mathrm{K}$ 量, 中性好性白血球百分率の符合を 変えて代数和した。な和各項目の規正のための標準值は 各項目の年間平均値を用いた。学童も同様にして求め, 各項目の規正のための標準値は全被検者の平均值と標準 偏差を用いた。との場合も同様に年間において多季節間 に沶いても, 成人及び学童男女間に自律神経緊張度の差 異を諗めなかつた。

以上によつて, 男女間の差は成人でも学童でもないて

\begin{tabular}{|c|c|c|c|c|c|c|c|c|c|c|c|}
\hline \multicolumn{4}{|c|}{ 中性好性白血球 } & \multicolumn{2}{|r|}{ リ } & \multicolumn{2}{|c|}{ パ 球 } & \multicolumn{4}{|c|}{ 酸 好 性 白 血 球 } \\
\hline $\mathbf{n}$ & $\mathbf{M}$ & $\mathbf{m}$ & $\sigma$ & $\mathbf{n}$ & $\mathbf{M}$ & $\mathrm{m}$ & $\sigma$ & $\mathbf{n}$ & $\mathbf{M}$ & $\mathbf{m}$ & $\sigma$ \\
\hline 363 & 58.22 & 0.440 & 8.070 & 363 & 31.10 & 0.396 & 7.575 & 363 & 4.14 & 0.175 & 3.274 \\
\hline 190 & 57.33 & 0.696 & 9.670 & 190 & 32.39 & 0.608 & 8.470 & 190 & 4.26 & 0.272 & 3.724 \\
\hline 124 & 61.80 & 0.751 & 8.365 & 124 & 29.20 & 0.643 & 7.155 & 124 & 3.50 & 0.225 & 2.488 \\
\hline 62 & 61.20 & 1.060 & 8.345 & 62 & 30.60 & 0.944 & 7.430 & 62 & 3.00 & 0.215 & 1.675 \\
\hline 114 & 54.60 & 0.859 & 7.915 & 114 & 33.90 & 0.536 & 5.725 & 114 & 4.40 & 0.350 & 3.556 \\
\hline 49 & 57.40 & 1.427 & 9.900 & 49 & 36.50 & 1.322 & 9.255 & 49 & 5.70 & 0.633 & 4.428 \\
\hline 71 & 57.60 & 1.049 & 8.840 & 71 & 30.80 & 0.920 & 7.810 & 71 & 6.10 & 0.394 & 3.298 \\
\hline 38 & 55.80 & 1.246 & 7.680 & 38 & 34.40 & 1.292 & 7.680 & 38 & 4.80 & 0.545 & 3.318 \\
\hline 54. & 58.50 & 1.016 & 7.483 & 54 & 29.70 & 0.874 & 6.540 & 54 & 4.20 & 0.463 & 3.430 \\
\hline 41 & 59.60 & 1.273 & 8.345 & 41 & 29.70 & 1.022 & 6.546 & 41 & 3.90 & 0.444 & 2.944 \\
\hline 91 & 48. 28 & 1.050 & 10.013 & 91 & 40.70 & 1.013 & 9.665 & 91 & 6.12 & 0.419 & 3.993 \\
\hline 108 & 48.75 & 0.992 & 9.586 & 108 & 41.12 & 0.903 & 9.390 & 108 & 5.67 & 0.406 & 4.217 \\
\hline
\end{tabular}




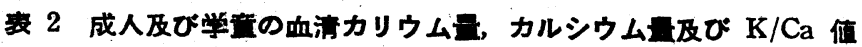

\begin{tabular}{|c|c|c|c|c|c|c|c|c|c|c|c|c|c|}
\hline \multirow{2}{*}{ 月 } & \multirow{2}{*}{$\begin{array}{l}\text { 年 } \\
\text { 令 } \\
\text { 別 }\end{array}$} & \multicolumn{4}{|c|}{ 血清カリウム $\mathrm{mg} / \mathrm{dl}$} & \multicolumn{4}{|c|}{ 血清カルシウム mg/dl } & \multicolumn{4}{|c|}{$\mathrm{K} / \mathrm{Ca}$} \\
\hline & & $\mathbf{n}$ & $\mathbf{M}$ & m & $\sigma$ & $\mathbf{n}$ & $\mathbf{M}$ & $\mathrm{m}$ & $\sigma$ & $\mathbf{n}$ & $\mathbf{M}$ & m & $\sigma$ \\
\hline \multirow{2}{*}{ 年間平均値 } & 成 & 524 & 19.51 & 0.094 & 2. 160 & 524 & 10.25 & 0.031 & 0.739 & 524 & 1.92 & 0.011 & 0.255 \\
\hline & 学 & 213 & 17.70 & 0.185 & 2.680 & 212 & 10.48 & 0.042 & 0.600 & 211 & 1.69 & 0.019 & 0.269 \\
\hline \multirow{2}{*}{3} & 成 & 68 & 19.34 & 0.283 & 2. 336 & 66 & 10.07 & 0.084 & 0.684 & 63 & 1.93 & 0.039 & 0.311 \\
\hline & 竸 & 96 & 16.76 & 0.194 & 1.905 & 96 & 10.35 & 0.059 & 0.582 & 96 & 1.62 & 0.019 & 0.189 \\
\hline \multirow{2}{*}{5} & 成 & 92 & 18.95 & 0.203 & 1.949 & 95 & 10.34 & 0.062 & 0.607 & 92 & 1.84 & 0.022 & 0.207 \\
\hline & 掌 & 57 & 16.28 & 0.159 & 1.203 & 57 & 10.67 & 0.062 & 0.469 & 57 & 1.53 & 0.018 & 0.138 \\
\hline \multirow{2}{*}{11} & 成 & 86 & 20.83 & 0.184 & 1.707 & 99 & 10.25 & 0.070 & 0.700 & 85 & 2.04 & 0.024 & 0.219 \\
\hline & 学 & 56 & 20.81 & 0.287 & 2. 146 & 56 & 10.49 & 0.098 & 0.722 & 56 & 2.00 & 0.034 & 0.245 \\
\hline
\end{tabular}

とが明らかになつたので，男女を併せて成人と学童との 比較を行つた。即ち5項目に更に $\mathrm{K} / \mathrm{Ca}$ 值, 平均核数, 白血 球数を加えて成人と学童の年間平均值（学童は3月,5月， 11 月の平均值）及び 3 月, 5 月，11月の各月平均値，標準 誤差及び標準偏差を計算した結果は表 2 一表 3 亿示すと おりである。表の $\mathrm{n}$ は各被検者数，Mは各平均值，mは 標準誤差及び $\sigma$ は標準偏差を示す。

以上の結果を要約すれば, 年間平均值では学童は成人 に比して，すべての項目に統計的に著明な有意性の差が あるとてろの血清 $\mathrm{K}$ 量の減少, 血清 $\mathrm{Ca}$ 量の增加, $\mathrm{K} / \mathrm{Ca}$ 值の減少, 中性好性白血球百分率の減少, リン八球百分 率の增加, 酸好性白血球百分率の増加, 白血球数の増加 及じ核の左方移動を認めた。3月，5月，11月でも同様な
美の傾向を認めたが 5 月では酸好性白血球百分率と白血 球数の 2 項目に，また11月では血清 $\mathrm{K}$ 量, 血清 $\mathrm{Ca}$ 量, $\mathrm{K} / \mathrm{Ca}$ 值, 酸好性白血球百分率, 白血球数, 核数の 5 項目 には統計的に有意性の差を認めなかつた。

てれを更に 原島1)，小川2）飞よる血液成分の絵合法 によつて調べた。即ち学童の全被検者の 5 項目の各平均 值を規淮として，各個体どと項目㓢にそれからへだたる 偏差を求め, それを学童の全被検者の標潐偏差で除した 商（規正した偏差）を個体別に血清 $\mathrm{K}$ 量, 中性好性白 血球百分率の符合を変えて代数和した。表4は学童196名 の規正偏差の個人別各月度数分布表である。

更にての分布の性質がどらであるかを知るために，実 測度数から正規分布曲線の囲む面積の確率積分 表10i）を

\section{衰 3 成人及び学童の白血球百分率，白血球数及び平均核数}

\begin{tabular}{|c|c|c|c|c|c|c|c|c|c|c|}
\hline \multirow{2}{*}{ 月 } & & \multirow{2}{*}{$\begin{array}{l}\text { 年 } \\
\text { 命 } \\
\text { 別 }\end{array}$} & \multicolumn{4}{|c|}{ 中性 好性白血球 } & \multicolumn{2}{|r|}{ リ } & ン & 球 \\
\hline & & & $\mathbf{n}$ & $\mathbf{M}$ & m & $\sigma$ & $\mathbf{n}$ & $\mathbf{M}$ & $\mathrm{m}$ & $\sigma$ \\
\hline \multirow{2}{*}{ 年 間 } & \multirow{2}{*}{ 平均值 } & 成 & 547 & 58.1 & 0.39 & 9.22 & 547 & 31.4 & 0.34 & 7.92 \\
\hline & & 学 & 205 & 49.6 & 0.59 & 8. 56 & 204 & 40.6 & 0.63 & 9.18 \\
\hline & \multirow{2}{*}{3} & 成 & 69 & 59.5 & 0.88 & 7.33 & 69 & 29.4 & 0.88 & 7.28 \\
\hline & & 学 & 96 & 47.5 & 1.09 & 10.01 & 96 & 40.5 & 1.02 & 10.06 \\
\hline \multirow{2}{*}{$\therefore$} & \multirow{2}{*}{5} & 盛 & 90 & 57.0 & 0.77 & 7.33 & 90: & 31.5 & 0.73 & 6.92 \\
\hline & & $\begin{array}{l}\text { 㸓 } \\
\end{array}$ & 57 & 47.4 & 1.44 & 10.70 & 57 . & 45.2 & 1.36 & .10 .06 \\
\hline \multirow{2}{*}{. } & \multirow{2}{*}{11} & 成 & 99 & 59.9 & 0.98 & 9.70 & 99 & 30,1 & 0.81 & 8.08 \\
\hline & & 学 & 56 & 53.9 & 0.88 & 6.69 & 56 & 36.1 & 0.79 & 5.98 \\
\hline
\end{tabular}


使つて理論度数を算出した。カイ自乗試験の結果（p⿳亠一𠃌

$0.50)$, 実測度数は理論度数 $\mathrm{y}=\frac{\mathrm{n}}{\sqrt{2 \pi \sigma}} \cdot \mathrm{e}^{\frac{-\mathrm{x}}{2 \sigma^{2}}}$

で表わされる正規分布と見做してよいととがわかつた。

次飞渡辺 ${ }^{5)}$ の得た成人安定体質者群の平均值を規準 とし, その標準偏差を利用して, 学童の自律神経緊張状 態の分布を成人と比較した。てのためには成人の安定体 質者群の平均檤を規準として，学童の全被検者の平均値 との各項目の偏差を求め, それを安定体質者群の標準偏 差で除した商を, 前に述べた 2 項目の符合を変えて代数

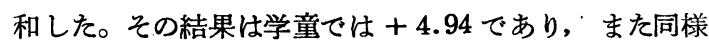
な方法で成人の年間平均值から計算を行えば +3.86 である。即ち学童は成人に比して，血液成分の総合法に よる自律神経聚張度は, 4.94 または 3.86 だけ副交感神 経緊張に傾いているものと思われる。成人の春秋の理論 曲線（115名） と学童の 3 月，5月，11月の理論曲線と の相異は 図 1 亿示すと和りである。成人の流行值は一 0.08 であり，学童の流行值は+ 4.94 である。即ち学童 は成人に比して副交感神経の側に偏移し, 成人との差は 成人の夏と冬5) との間にみられる季節変動（流行值の差 4.49）に注潘等しい程度である。

\section{3. 考按}

自律神経緊張状態の集団観察飞極めて合目的であると 渡辺によつて認められた血液による総合法を用いて，男 女及び年令による相異をみた。

成年男女間及び学童男女間の自律神経緊張状態の差異 につレての業績は全くない。ただ 外山11) は 5 項目中男 女に最も差の大きいのは血清 $\mathrm{Ca}$ 量であるととを知つた

\section{図 1 成人と学音の自律神経等張度の度数分布表}

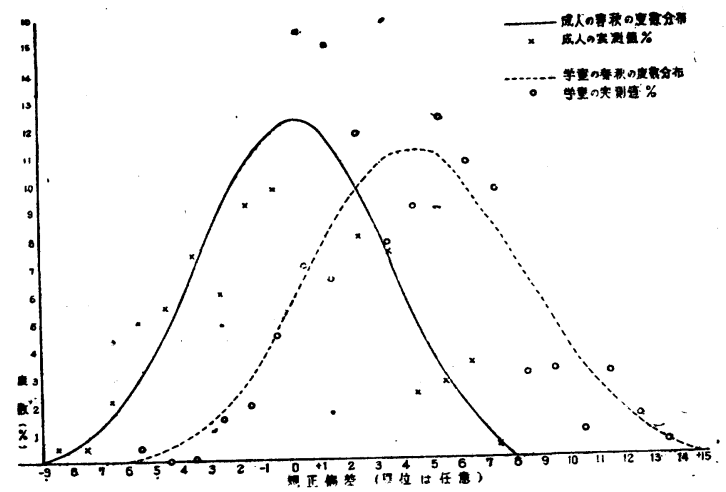

が, 本実験でも 5 項目中血清 $\mathrm{Ca}$ 量が統計的な有意性は ないが，特に成人の年間平均值及び秋と春にやや著明な 減少を女に認めた。しかし血液の総合法により男女間の 自律神経緊張度を比較したが差異を認めなかつた。

学童が成人に比して副交感神経緊張に傾いているてと は既に認められている。学童の血清Ca量については, 最 初菊地氏 ${ }^{12)}$ が井上氏変法により平均值 $10.12 \mathrm{mg} / \mathrm{dl}$ を得, 最近水野13) は Sobel-Skersky 氏法で平均值 10.10 $\mathrm{mg} / \mathrm{dl}$ ，また Hawland-Kramer は 1921年 Kramer-Tisdall 氏法により平均値 $10.7 \mathrm{mg} / \mathrm{dl}$ を得ている。水野 ${ }^{13)}$ は成人に比較して血清 $\mathrm{Ca}$ 量は学童以前はやや増加の傾 向を認め,また生理的動摇範囲の大であるととを述べて いる。本実験に和いても成人平均值 $10.25 \mathrm{mg} / \mathrm{dl}$ K比

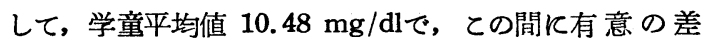
を認めた。血液像の年令による相異は 杉14) とより, 成

\begin{tabular}{|c|c|c|c|c|c|c|c|c|c|c|c|}
\hline \multicolumn{4}{|c|}{ 酸 好性 白血 球 } & \multicolumn{2}{|r|}{ 白 } & \multicolumn{2}{|c|}{ 数 } & \multicolumn{2}{|r|}{ 平 } & 核 & 数 \\
\hline $\mathrm{n}$ & $\mathbf{M}$ & $\mathrm{m}$ & $\sigma$ & $\mathbf{n}$ & $\mathbf{M}$ & $\mathrm{m}$ & $\sigma$ & $\mathrm{n}$ & $\mathbf{M}$ & $\mathrm{m}$ & $\sigma$ \\
\hline 547 & 4.2 & 0.14 & 3.26 & 547 & 6848 & 66.70 & 1392.86 & 436 & 2.09 & 0.011 & 0.260 \\
\hline 205 & 6.2 & 0.29 & 4. 26 & 191 & 7651 & 128.75 & 1843.55 & 204 & 1.92 & 0.019 & 0.274 \\
\hline 69 & 3.8 & 0.32 & 2.64 & 67 & 7523 & 128.89 & 1055.00 & 69 & 2.13 & 0.032 & 0.268 \\
\hline 96 & 7.1 & 0.54 & 5.02 & 96 & 8395 & 274.48 & 2475.88 & 96 & 1.96 & 0.028 & 0.257 \\
\hline 90 & 4.0 & 0.39 & 3.74 & 90 & 6720 & 115.69 & 1097.59 & 90 & 2. 18 & 0.030 & 0.283 \\
\hline 57 & 5.2 & 0.48 & 3. 49 & 57 & 6820 & 154.64 & 1177.71 & 57 & 1.70 & 0.032 & 0.242 \\
\hline 99 & 4.3 & 0.29 & 2.87 & 106 & 6882 & 136.94 & 1409.91 & 109 & 2.09 & 0.023 & 0.237 \\
\hline 56 & 5.3 & 0.45 & 3.42 & 56 & 7065 & 183.00 & 1357.86 & 56 & 2. 04 & 0.032 & 0.247 \\
\hline
\end{tabular}




\begin{tabular}{|c|c|c|c|c|c|c|c|c|}
\hline & 数分 & 布表 & & & & & & \\
\hline+10 & & & & • & & & & \\
\hline 9 & & & & & 1) & & 1 & \\
\hline 8 & & & 1 & & 2 & & 3 & \\
\hline 7 & & & 5 & & 1 & & 6 & \\
\hline 6 & & & 2 & & 0 & & 2 & \\
\hline 5 & & & 5 & & 3 & & 8 & \\
\hline 5 & & & 4 & $64 \%$ & 4 & $74 \%$ & 8 & $57 \%$ \\
\hline 3 & & & 11 & & 8 & & 19 & \\
\hline 2 & $2)$ & & 12 & & 7 & & 21 & \\
\hline+ & $3\}$ & $19 \%$ & 11 & & 12 & & 26 & \\
\hline & 3 & & 10 & & 5 & & 18 & \\
\hline-1 & 3) & & 9 & & 5 & & 17 & \\
\hline 2 & 9 & & 10 & & 4 & & 23 & \\
\hline 3 & 5 & & 4 & & 4 & $26 \%$ & 13 & \\
\hline 4 & 8 & & 6 & $36 \%$ & 0 & & 14 & \\
\hline 5 & 6 & & 2 & & 1 & & 9 & \\
\hline 6 & 1 ( & $81 \%$ & 3 & & & & 4 & $43 \%$ \\
\hline 7 & 2 & & 1 & & & & 3 & \\
\hline 8 & 0. & & & & & & 0 & \\
\hline 9 & 0 & & & & & & 0 & \\
\hline-10 & $1^{\prime}$ & & & & . & & 1 & \\
\hline 月 & 11 & & 3 & & 5 & & 計 & \\
\hline 計 & 43 & & 96 & & 57 & & 196 & \\
\hline
\end{tabular}

人になるに従い淋巴球の漸次減少を認め,ての淋巴球は アズール顆粒を含む淋巴球の隇少であり，成人の值に達 するのは，男子18才，女子15才一17才であるといつてい る。血液百分率を志摩 ${ }^{15}$ ，酒井 ${ }^{18)}$ 等の 10 才一15才の学 童平均值と比較すると, 本実験任百分率算定法が屈折法 によつたのにもかかわらず，遥が中性好性白血球百分 率が少ない。この原因は被検者の集団の種々なる因子と， 探血の季節, 採血場所, 採血時間のためと思われる。

本研究では, 学童と成人との血液の各種成分の差を実 証したばかりでなく，それらの個々の数值を整頓して， 自律神経緊張状態を緿合的に測定して，それが学童では 成人に比して副交感神経緊張の方に傾き，しかも，その 程度の大きさを決定した。とれは図 1 亿示すと和りで ある。

検査法について一㝘する。採血時間を一定としたのは, Müller ${ }^{17) ~}$ は疲労に際して血策のK及没びCaが增し，恢復 に際して減少するとし，また血液像についても特に白血 球数は変化し易く，Mac Gregor 等 ${ }^{18)}$ は立位では臥位上 りも少まいと論じているために，著者は採血はすべて午
前 10時一12時の間の安静時臥位で行つた。血清 K の測 定法 Kramer-Tisdall ${ }^{6}$ 氏法は，外山3 名認めているよ らに，相当の実験誤差を認めねばならないが，著者は血 清分離に注意した結果, 誤差を小さくするととができた。 即ち R. M. Tenery and C.E. Anderson ${ }^{19)}$, 合原 20 ) によつて認められたように，探血後の血球中の Kは血清 中に漸次移行しつつあるとと，それが外界の条件と関媇 のあるととからなるべく早く血清を分離する。また,少 量の赤血球の血清中への混入は識別し難らので, 血清量 は定量以上垔必要とし，また再度遠沈するがよい。溶血 したものは全く除外しなければならない。冬は血清分離 が困難なために，よく注意して行ら必要を想あた。

白血球百分率算定は, Mac Gregor ${ }^{8)}$ 等の届折泆の 方が広く行われている横断法より全数算定による真値に 近いととが明らかであるから，著者も屈折法に従つた。 全被㭘者に検便を行つたが，酸好性白血球百分率と蜔虫 症との間には相関が認められなかつた。

\section{4. 悢括 及び結論}

成人 568 名, 学童 212 名について, 男女間, 年令の相 異についての自律神経緊張度を検查した結果

1) 成人及ど学童（10才一11才）の男女間には，血清 $\mathrm{K}$ 量, 血清 $\mathrm{Ca}$ 量, $\mathrm{K} / \mathrm{Ca}$ 值, 中性好性白血球百分率, リン パ球百分率，酸好性白血球百分率の 5 項目には, 統計的 に有意な差が認められない。また，血液の総合法による 自律神経聚張状態につレても，有意な差が認められなか つた。

2) これらの 5項目に対し, 健康成人と健康学童 $\left(1^{0}\right.$ 才一11才) 間の差は著明で，学童は成人に比して，血清 $\mathrm{K}$ 量の減少，血清 $\mathrm{Ca}$ 量の増加，中性好性白血球百分率 の減少, リンパ球百分率の増加, 酸好性白血球百分率の 增加が認められ，また $\mathrm{K} / \mathrm{Ca}$ 值の減少，白血球数の増加 があり，平均核数は左方移動を示している。

3）学童の自律神経系の緊張度の分布が，成人と 同様 な正規分布であるととを知り，成人との差は春秋におい て学童の方が. +4.94（成人の安定体質者群を規準とし て），または，+3.84（成人の年間平均值を規準とし て）だけ副交感神経㹂張に傾いているととを䜑めた。

終りに臨み御指導と御校閲を賜わつた原島進教授に哚 謝する。

\section{参 考 女 献}

1）原島進；南方民族の体質研究（未発表）

2) 小川隆男; 気候の自律神経系統に及攺す影響（未 発表) 
3）外山敏夫；季節変動に対する血液成分の反応，第1 編, 健康成人の血液成分の季節変動 $(1)$; 第2編, 健康 成人の血液成分の季節変動 (2); 第 3 編, 血液成分の季 節変動からみた自律神経婜㲀状態 (未発表)

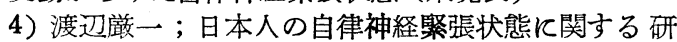
究, 第 1 編, 薬效的及び理学的検查の判定規準と自律神 経緊張状態の分類についての検討 (未発表)

5）渡辺撖一；血液成分の綜合判定による日本人の自 律神経緊張状態（未発表）

6) Kramer, B. and Tisdall, F. E.; The direct quantitative determination of sodium, potassium, calcium and magnecium in small amount of serum, Journ. Biol. Chem., 63, 461, 1925

7) Clark, E. P. and Collip, J. B. ; The study of Tisdall Method for the determination of blood se$\mathrm{r} \cdot \mathrm{Im}$ calcium with a suggested modification, Journ. Biol. Chem., 48, 223, 1921

8) R. G. Scott Mac Gregor, W. Richards and G. L. Loh; The Differential Leucocyte Count, Journ.Pathol. and Bactl., 51, 337, 1940

9). 杉山繁輝; 血液及び組織の新研究と其の方法, 118 頁, 昭和 16 年

10）古屋芳雄; 医学統計法の理論と其の応用, 附録 1頁, 5 頁, 昭和 9 年
11）外山敏夫;（未発表）

12）菊地清一; 結核児童の血清「カルシウム」含有量 飞就て, 結核, 3, 393, 大正14年

13）水野光大；小児血清カルシウムに関する研究，其 の1, 本邦健康小児血清カルシウム量並びに年令的差異, 児科雑誌, $53,1-2$ 号, 昭和 24 年

14）杉純一郎; 健康者血液像の年令几依る変化飞関す る綜説, 九州医学専門学校医学会雑誌, 2,168 , 昭和 12 年

15）志摩次郎；叙抹標本に依る健康児童の血球及ど赤 血球の所胃飞就て, 児科雑誌, 234,373 , 大正 9 年

16）酒井幹夫; 本邦小児の正常血液所見, 児科雑誌, 245,376, 大正 9 年

17) Müller, L. R. ; Über Ermüdung und Erholung, Klin. V schr., 18,113, 1939

18) R. G. Scott Mac Gregor and G L. Loh ;The comparison of basal physiological values in racial groups, part 3. Leucocytes, Journ. Malay. Br. B.M. A., 4, 405, 1941

19) R. M Tenery and C. E. Anderson; Determination of Potassium in Plasma, Journ. Biol. Chem., $135,659,1940$

20）合原義泰；（未発表）

（受付：1954年11月6日） 